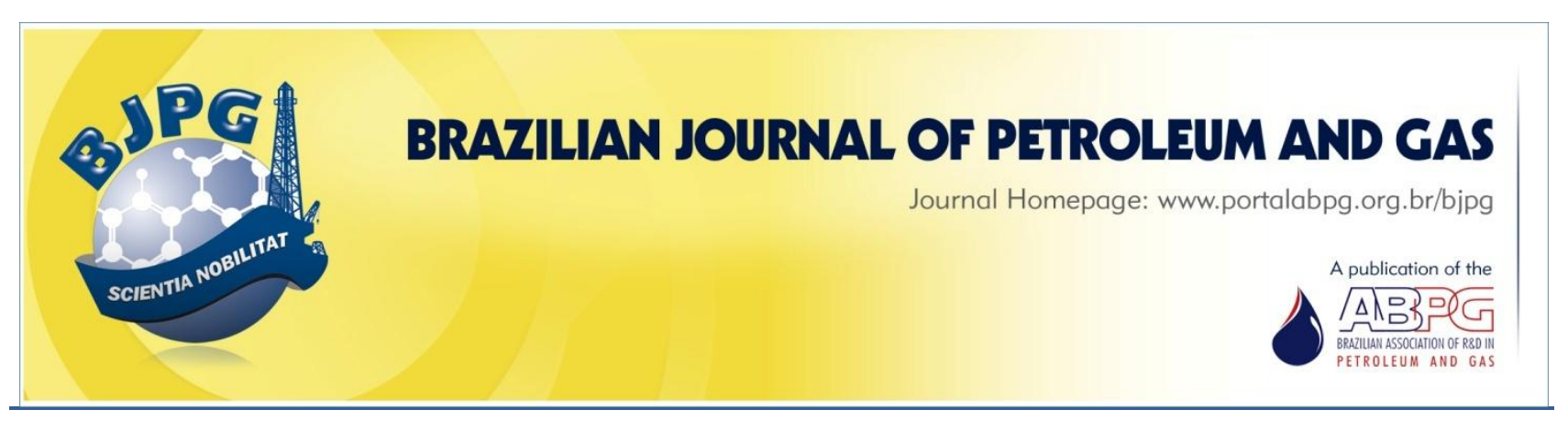

\title{
PERFORMANCE OF NATURAL SODIUM CLAY TREATED WITH AMMONIUM SALT IN THE SEPARATION OF EMULSIFIED OIL IN WATER
}

\author{
${ }^{\text {a }}$ Oliveira, G. C.; ${ }^{a}$ Mota, M. F.; ${ }^{a}$ Silva, M. M. ; ${ }^{a}$ Rodrigues, M. G. F. ${ }^{1}$; ${ }^{a}$ Laborde, H. M. \\ ${ }^{\mathrm{a}}$ Federal University of Campina Grande, Academic Unit of Chemical Engineering, Campina Grande, Brazil
}

\begin{abstract}
This study aims to characterize and evaluate the use of adsorbent (organoclay) in the process of separation of oil in water emulsion. One goal of this work is to prepare and characterize untreated sodium clay (BSN-03) from Argentina and treated BSN-03. The method used to prepare the organoclay replaces the cations $(\mathrm{Na}+)$ interlayer of the clay by a quaternary ammonia cation. Tests used X-ray diffraction to observe the obtaining of organoclays. The spectrum showed that the distance of the basal clay BSN-03 was modified, indicating that the quaternary ammonium salt was intercalated. Infrared data show that the ammonium salt was incorporated into the clay structure, thereby confirming organophilization. After the preparation and characterization of the organoclay, oil removal capacity (qeq) and the percentage of oil removal (\%Rem) of the adsorbent (BSN-03) was observed through a finite bath system. Finite bath tests determined the rate and capacity of oil removal by the treated clay. Up to $49.50 \mathrm{mg} / \mathrm{g}$ of oil removal capacity ( $98.99 \%$ efficiency) was reached, indicating that the clay treated with CTAC is an excellent alternative in the process of oil removal.
\end{abstract}

\section{KEYWORDS}

bentonite clay; organoclay; surfactant; oil in water emulsion; separation process

\footnotetext{
${ }^{1}$ To whom all correspondence should be addressed.

Address: Academic Unit of Chemical Engineering, Federal University of Campina Grande (UFCG), Av. Aprígio Veloso, 882 -

Bodocongó - Campina Grande - Paraíba - Brazil - CEP 58429-970.

Telephone: +55 83 2101-1488 / +55 83 2101-1115 | E-mail: $\underline{\text { meiry@deq.ufcg.edu.br }}$

doi:10.5419/bjpg2012-0014
} 


\section{INTRODUCTION}

In oil production operations it is often necessary to handle the brine that is produced along with the crude oil (oil-field brine). This brine must be separated from the crude oil and disposed of in a manner that does respect environmental laws and regulations. In offshore areas the governing regulatory body specifies the maximum hydrocarbon content in water that is allowed to be discharged overboard (Okiel et al., 2011).

Due to the potential hazards that oil field effluents can cause to the environment, treatment is necessary prior to its disposal. The regulations require that non-dissolved and dissolved components should be reduced or removed from the wastewater. The treatment of these effluents may result in enhanced oil/water separation, improved water quality, oil recovery, water reuse, protection of downstream facilities, and compliance with environmental permits (Bande et al., 2008).

Many techniques are available for the separation of emulsified oil from water. These techniques include the use of a variety of filters, chemical dosing, reverse osmosis, gravity separation, ultra and micro-filtration, biological processes, air flotation, membrane bioreactors, chemical coagulation, electrocoagulation and electroflotation. The process of adsorption is one technique used largely for removing organics dissolved in water. This process involves the separation of substances from one phase to the surface of another (Campos et al., 2002; Scholz \& Fuchs, 2000).

Oil adsorption by activated carbon is the most widely used method, since this adsorbent has the ability of extracting organic compounds of low molecular weight from the effluents. Moreover, coal has a high porosity level and presents surface heterogeneity. However, the disadvantage of using activated carbon resides in its high commercial price. There are many studies that propose substitutes for the activated carbon, which would also avoid the need of many material precursors (Srivastava et al., 2006).

Yuri et al. (2011) reported that many studies have been investigating the increase in the adsorption capacity of organic clays; effected by the exchange of natural inorganic cations which are located within the clay layers by organic cations.

The use of clay modified by quaternary ammonium salts has been shown to remove efficiently organic compounds of low solubility in water. Although there are other types of adsorbents used to remove most of the pollutants, pores are susceptible to blockage in the structure caused by large hydrocarbons. In this context, chemically modified clays are used in the removal of oil (Alther, 2008).

Alternative processes for oil-water separation by adsorption using clays have been investigated. Clay samples from the smectite group, a group of aluminosilicates that has montmorillonite as the primary clay mineral, have shown promising results. The knowledge of such properties is important to fundamental research.

Gonzaga et al. (2007) performed a study on the preparation of organophilic clay from the Argel bentonite and cetyltrimethylammonium chloride (CTAC). The results confirmed the attainment of organophilic materials. The study shows that these materials exhibited good capacity to adsorb organic solvents when tested in gasoline, diesel, methanol, ethanol, toluene and acetone.

Rodrigues et al. (2010a) used gray clay treated with cethyltrimethyl ammonium bromide (CTAB) to obtain $37.57 \mathrm{mg} / \mathrm{g}$ (94.54 \% efficiency) of oil removal capacity. Mota et al. (2011) used green clay treated with alkyldimethylbenzil ammonium chloride (Dodigen) to reach $32.50 \mathrm{mg} / \mathrm{g}$ (99.30\% efficiency) of oil removal capacity in the assays. Both tests used $2^{2}$-factorial designs with three central points to determine the rate and capacity of oil removal by the organophilic clays. The test samples used Brazilian clays, but different ammonium salts quaternaries under the same test conditions.

Our research group (LABNOV / Development of New Materials Laboratory, UFCG, Brazil) has published a series of papers on the preparation and characterization of organoclays (Gonzaga et al., 2007; Rodrigues et al., 2010a, and Mota et al., 2011). The present work is part of this research line, and represents another contribution to the field in order to understand how organoclay behaves as an adsorbent with different characteristics. All clays used in previous studies were Brazilian policationic and each one was 
unique, presenting peculiar characteristics.

Therefore, this work aims to elucidate the alterations in the properties of sodium clays after organic treatment. Additionally, this work assesses the organoclay potential in the process of oil removal in a system comprised by emulsified oil in water, by series of finite bath tests in laboratory scale. The influence of the emulsion initial concentration and the rate of agitation of the system on the oil removal could be determined by a variance analysis.

\section{EXPERIMENTAL}

\subsection{Materials}

The experiment used natural sodic bentonite (BSN-03) clay from Argentina. The material was provided by Bentonisa (Brazil) and was sieved according to the Brazilian ABNT standard $\mathrm{N} \cong 200$ $(0.074 \mathrm{~mm})$. The surfactant used was cetyltrimethyl ammonium chloride (CTAC), purchased from Clariant.

\subsection{Treatment with quaternary ammonium salt}

The experiments used a treatment technique adapted from the procedure proposed by Mota et al. (2011). The need for modifications in the technique came from the fact that the clay used in this work is naturally sodic, different from the one used by the abovementioned authors. Figure 1 shows the stages of the sodium clay organophilization process.

Initially, a dispersion of clay (4\% in weight) in distilled water was prepared under agitation for 30 minutes. Then, $9.8 \mathrm{~g}$ of the quaternary ammonium salt was added to the dispersion, and the mixture was stirred for a further 30 minutes. The solid sediments were filtered out, dried at a temperature that ranged from 60 to $65^{\circ} \mathrm{C}$ for 48 hours, disintegrated and sieved in an ABNT $\mathrm{N}^{\circ} 200$ $(0.074 \mathrm{~mm})$ sieve.

\subsection{Characterization}

Table 1 shows the techniques used in the characterization of the clays.

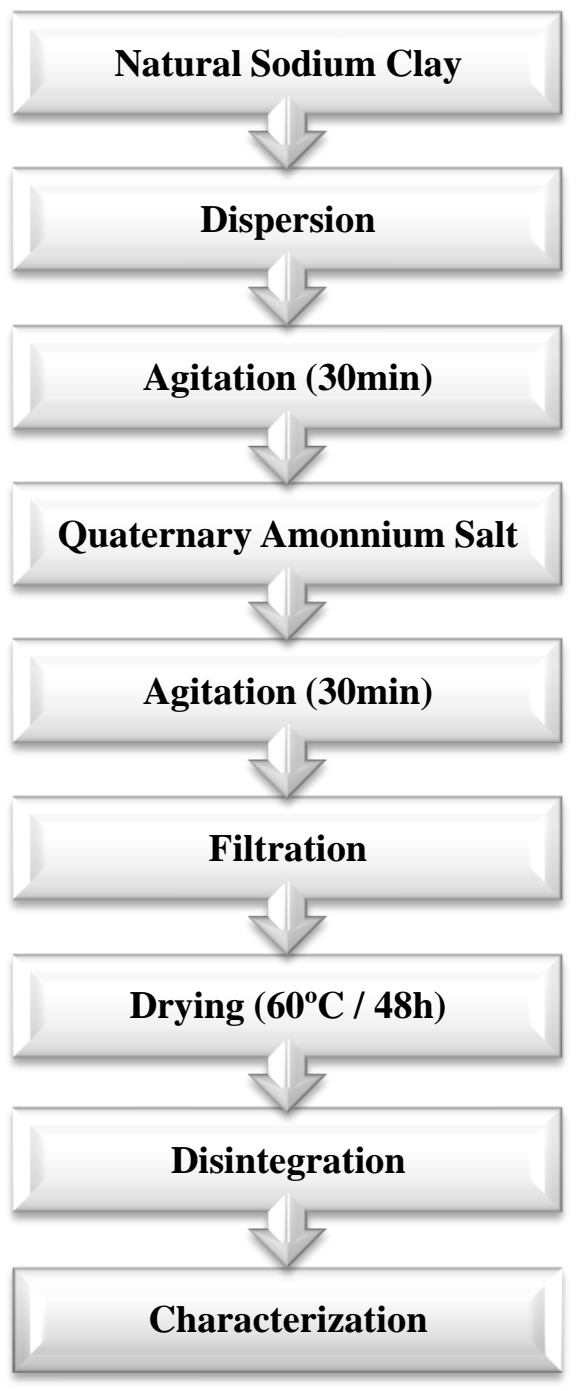

Figure 1. Stages of the sodium organophilization process.

\subsection{Analysis of variance of the separation process}

A factorial design was proposed to analyze the influence of initial oil concentration in aqueous solution $\left(C_{0}\right)$ and the mechanical agitation of the system (A) on the separation of emulsified oil in water emulsions. The variables obtained from this study were: the total oil removal percentage (\%Rem) and the capacity of oil removal at equilibrium $\left(q_{e q}\right)$ as suggested by Mota et al. (2011) and Rodrigues et al. (2010b). The analysis of variance was performed using the Minitab 16.1 Software. The values for levels $(+1)$ and $(-1)$ are shown in Table 2. 
Table 1. Clay characterization techniques.

\begin{tabular}{|c|c|c|}
\hline Analysis & equipment & Parameters / observations \\
\hline $\begin{array}{l}\text { Physical Adsorption of } \\
\mathrm{N}_{2}\end{array}$ & $\begin{array}{l}\text { Micromeritics surface area } \\
\text { and porosity analyzer, } \\
\text { model ASAP } 2020 .\end{array}$ & BET method \\
\hline $\begin{array}{l}\text { Cation Exchange } \\
\text { Capacity }\end{array}$ & $\begin{array}{l}\text { Marconi nitrogen distiller, } \\
\text { model MA-036Plus. }\end{array}$ & $\begin{array}{l}\text { "Standard Test Method for Measuring the Exchange } \\
\text { Complex and Cation Exchange Capacity of Inorganic } \\
\text { Fine-Grained Soils" (ASTM D7503-10). }\end{array}$ \\
\hline X-Ray Diffraction & $\begin{array}{l}\text { Shimadzu X-ray } \\
\text { diffractometer, model XRD- } \\
6000 .\end{array}$ & $\begin{array}{l}\text { Copper Ka radiation at } 40 \mathrm{kV} / 30 \mathrm{~mA} \text {, with } \\
\text { goniometer velocity of } 2^{\circ} / \mathrm{min} \text { and a step of } 0.02^{\circ} \text {, } \\
\text { with } 2 \theta \text { ranging from } 2^{\circ} \text { to } 45^{\circ} \text {. The only d-spacings of } \\
\text { interest in the } X \text {-ray patterns were the basal spacing } \\
\text { along the } \mathrm{c} \text { axis. }\end{array}$ \\
\hline Infrared Spectroscopy & $\begin{array}{l}\text { Pro-Analysis } \\
\text { spectrophotometer, model } \\
\text { UV-1600. }\end{array}$ & $\begin{array}{l}\text { The samples were submitted to a physical treatment } \\
\text { similar to the one used in the } \mathrm{KBr} \text { method. The } \\
\text { analysis was performed with wavelengths ranging } \\
\text { between } 4000 \text { and } 400 \mathrm{~cm}^{-1} \text {. }\end{array}$ \\
\hline $\begin{array}{l}\text { Differential Thermal } \\
\text { and } \\
\text { Thermogravimetric } \\
\text { Analyses }\end{array}$ & $\begin{array}{l}\text { Shimadzu thermal analyzer, } \\
\text { model DTG }-60 \mathrm{H} \text {. }\end{array}$ & $\begin{array}{l}\text { Operating at a ramp of } 10 \mathrm{~K} / \mathrm{min} \text { from room } \\
\text { temperature up to } 1273 \mathrm{~K} \text {, under a nitrogen } \\
\text { atmosphere, at a flowing a rate of } 50 \mathrm{~mL} / \mathrm{min} \text {. }\end{array}$ \\
\hline Foster Swelling Test & & $\begin{array}{l}\text { Gasoline (Petrobras), diesel (Petrobras) and kerosene } \\
\text { (Ares) samples were used in assays based on the } \\
\text { "Standard Methods of Testing Sorbent Performance } \\
\text { of Adsorbents" (ASTM F716-82). }\end{array}$ \\
\hline Adsorption Capacity & & $\begin{array}{l}\text { The sorption capacity of gasoline (Petrobras), diese } \\
\text { (Petrobras), and kerosene (Ares) samples was } \\
\text { determined according to the "Standard Methods of } \\
\text { Testing Sorbent Performance of Adsorbents" (ASTM } \\
\text { F726-99). }\end{array}$ \\
\hline
\end{tabular}

Table 2. $2^{2}$ - factorial experimental design.

\begin{tabular}{c|c|c|c|c}
\hline Test & $\begin{array}{c}\text { Concentration } \\
(\mathrm{ppm})\end{array}$ & $\begin{array}{c}\text { Agitation } \\
(\mathrm{rpm})\end{array}$ & $\begin{array}{c}\text { Coded } \\
\text { Concentration } \\
(\mathrm{ppm})\end{array}$ & $\begin{array}{c}\text { Coded } \\
\text { Agitation } \\
(\mathrm{rpm})\end{array}$ \\
\hline 1 & 100 & 0 & -1 & -1 \\
\hline 2 & 500 & 0 & +1 & -1 \\
\hline 3 & 100 & 200 & -1 & +1 \\
\hline 4 & 500 & 100 & +1 & +1 \\
\hline 5 & 300 & 100 & 0 & 0 \\
\hline 6 & 300 & 100 & 0 & 0 \\
\hline 7 & 300 & & 0 & 0 \\
\hline
\end{tabular}

\subsection{Finite bath system}

The finite bath tests were prepared according to the experimental design. A total of $0.5 \mathrm{~g}$ of the adsorbent was added to $50 \mathrm{~mL}$ of oil (LUBRAX MG1) emulsified in water with concentrations 100, 300 , or 500 ppm, depending on the test. After adding the adsorbents, the suspension (emulsion + adsorbent) was allowed to stir mechanically in an orbital shaker for 6 hours, to ensure the equilibrium of the system (Mota et al., 2011; Rodrigues et al., 2010b).

The concentrations of oil at equilibrium were determined by absorbance analysis, using a UVvisible spectrophotometer. An analytical curve was constructed by plotting the absorbance versus the oil concentration, which ranged from 0 to $100 \mathrm{ppm}$ $(0,10,20,30,40,60,80,100)$ of oil. 
After a six-hour period, the samples were filtered and, from the filtrate. a $10 \mathrm{~mL}$ aliquot was collected from each sample. Following, $10 \mathrm{~mL}$ of chloroform were added to act as oil extractor in the liquid/liquid extraction, because the chloroform has a significant peak at $262 \mathrm{~nm}$. According to Greenberg et al. (1985) and Henderson et al. (1999), at this wave length the absorbance is commonly used to estimate the concentration of oil in produced water and indicate the bands of aromatic $\mathrm{C}-\mathrm{H}$. The samples were, again, stirred in the orbital shaker for 5 minutes at 100rpm. After stirring, there was a formation of two phases: a denser one of oil solubilized in chloroform, and another with the remaining water from the emulsion. The collection of the denser phase was done with a glass syringe and transferred to a quartz cuvette, where the liquids were put into the spectrophotometer for reading.

The total oil removal percentage (\%Rem) and the capacity of oil removal at equilibrium ( $q_{\text {eq }}$, in $\mathrm{mg}$ of oil/g of adsorbent) were obtained with Equations 1 and 2, respectively:

$\% \operatorname{Rem}=\left(\frac{\mathrm{C}_{0}-\mathrm{C}_{\mathrm{eq}}}{\mathrm{C}_{0}}\right) * 100$

$\mathrm{q}_{\mathrm{eq}}=\frac{\mathrm{V}}{\mathrm{m}}\left(\mathrm{C}_{0}-\mathrm{C}_{\mathrm{eq}}\right)$

Where, $C_{0}$ is the initial concentration of oil in the emulsion, in $\mathrm{mg} / \mathrm{L} ; \mathrm{C}_{\text {eq }}$ is the final concentration of oil in the emulsion, in $\mathrm{mg} / \mathrm{L} ; \mathrm{V}$ is the volume of adsorbate, in $\mathrm{mL}$; and $\mathrm{m}$ is the mass of adsorbent, in $\mathrm{g}$.

\section{RESULTS AND DISCUSSION}

The crystallographic structure of montmorillonite was characterized by X-ray diffraction (XRD) (Figure 2). XRD patterns indicate the information of the existence of two categories on the crystallographic structure. The first category, or class, displayed basal 001 reflections which depended on the nature of the interlayer cations, the state of hydration of the mineral (thickness and regularity of the water layers between the silica sheets), and the presence of other intercalated molecules (such as ammonium salts). Due to the variability of the basal 001 reflections caused by intercalated water molecules, no table of classification can be established for them (Brindley and Brown, 1980).

The second class contains two-dimensional Huygens-Kirchhoff (HK) diffraction bands, which are characteristic of smectite layers structures, and are independent from the basal spacing. These HK diffraction bands are correlated in all smectites. These bands are not very appropriate in the determination of structures because of the nature of the diffraction process and the fact that each band observed is the sum of several HK index pairs. Thus, only a "trial and error" procedure is possible. In these trial procedures bands are calculated for different structure models and confronted with the observed data. Moreover, montmorillonite cannot be totally isolated from impurities, which makes the analysis by XRD even more difficult.

The XRD is the most widely used technique for the study of surfactants inserted in the silicate galleries. They provide information on the surfactant layering structure. The orientation of the intercalated alkyl ammonium molecules can be indirectly obtained on the basis from the basal $d$ value.

Figures 2 and 3 show the $X$-ray diffractograms of both the untreated and treated BSN-03 clays. The XRD obtained for the untreated BSN-03 clay presented a peak with reflection at $1.478 \mathrm{~nm}$, which is typical of smectites. Peaks at $0.448 \mathrm{~nm}$ and $0.335 \mathrm{~nm}$ could also be observed. These peaks occurred due to the presence of quartz impurities (Sousa Santos, 1989). The diffractogram of the BSN-03 clay treated with CTAC could verify that the interlamellar distance $\left(\mathrm{d}_{001}\right)$ increased to $2.074 \mathrm{~nm}$, which was an indication of the intercalation of the ammonium quaternary cation of the surfactant in the clays. Similar values corroborate the values obtained by Gonzaga et al. (2007) for Argel clay. That clay had characteristics that were similar to the ones obtained in this experiment, since the same surfactant was used in both studies. The results of the basal spacing were $1.28 \mathrm{~nm}$ for natural clay and $1.92 \mathrm{~nm}$ for the treated one.

The specific surface area (SSA) of clay minerals and related materials is one of the most important properties controlling surface phenomena. The SSA of non-swelling and non-microporous phyllosilicates ranges from a fraction to more than one hundred square meters per gram. Higher values are reached with microporous clay minerals, 


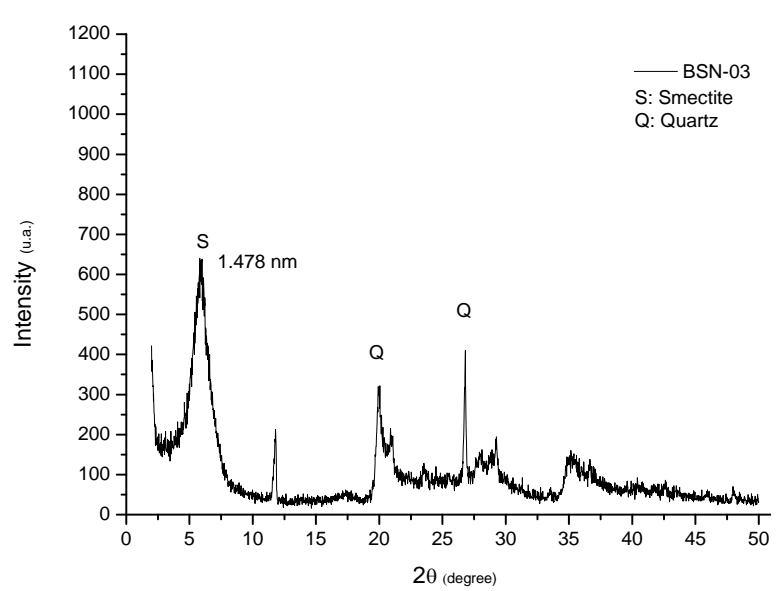

Figure 2. Diffractogram of the untreated BSN-03 clay.

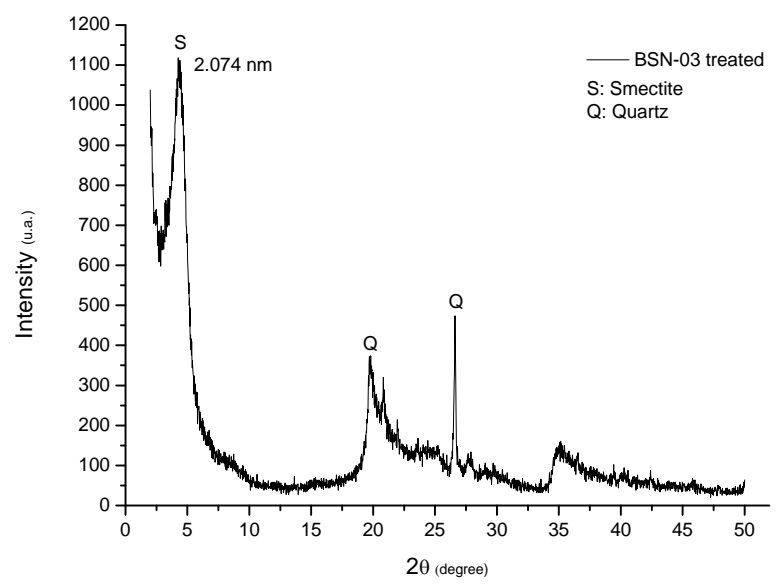

Figure 3. Diffractogram of the treated BSN-03 clay.

Table 3. Textural properties of untreated BSN-03 clay.

\begin{tabular}{cccc}
\hline \multirow{2}{*}{ Sample } & $\begin{array}{c}\text { Specific } \\
\text { Surface Area } \\
\left(\mathrm{m}^{2} / \mathrm{g}\right)\end{array}$ & \multicolumn{2}{c}{ Volume $\left(\mathrm{m}^{3} / \mathrm{g}\right)$} \\
\cline { 3 - 4 } & 120 & $1.108 \times 10^{-8}$ & $1.426 \times 10^{-7}$ \\
\hline BSN-03 & &
\end{tabular}

such as the sepiolite and the palygorskite, and by swelling (expanding) clay minerals. Since clay minerals can take up organic and inorganic molecules at solid-liquid or solid-gas interfaces, they play an important role in natural and industrial processes. The surface properties of these minerals have to be determined precisely if an insight into the underlying mechanisms is to be provided (Bergaya et al., 2006).
The results of specific surface area (SSA) are shown in Table 3. The surface area of untreated BSN-03 clay is $120 \mathrm{~m}^{2} / \mathrm{g}$. This value is higher than the one obtained by Rodrigues (2003) for the Red Clay, $103 \mathrm{~m}^{2} / \mathrm{g}$. These values indicate that untreated BSN-03 clay has a better adsorption capacity than Red Clay.

The differences between the volume of micro and mesopores can be better visualized in Figure 4, which depicts the nitrogen adsorption isotherm.

This isotherm is typical of the formation of multiple layers of adsorbed molecules on the solid surface. This type of isotherm is often found on non-porous solid or materials with pores that are larger than micropores. This characteristic explains the low value of micropore volume (Bergaya and Lagaly, 2001).

The untreated BSN-03 clay had a Cation Exchange Capacity (CEC) value of 77 milliequivalents per 100 grams of clay. Grim (1962) stated that high CEC values, with levels between 80 and 150 milliequivalents per 100 grams of clay, indicate that the clay has a low amount of impurities or a high isomorphic substitution level. Based on this premise, the value of the cationic exchange capacity is in agreement with the expected range for smectite clays. For the untreated gray clay, Rodrigues et al. (2010b) reported a cation exchange capacity of about 84 milliequivalents per 100 grams, similar to the capacity of the clay used in this work.

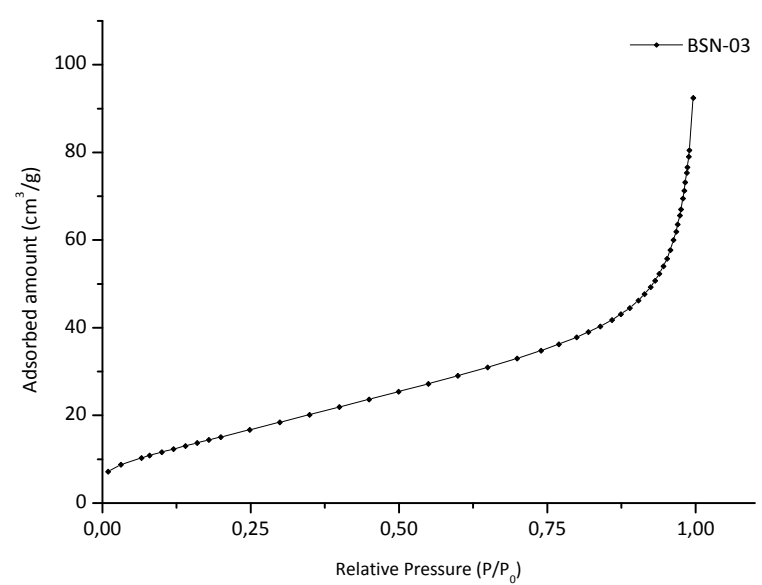

Figure 4. Nitrogen adsorption isotherm of the untreated BSN-03 clay. 


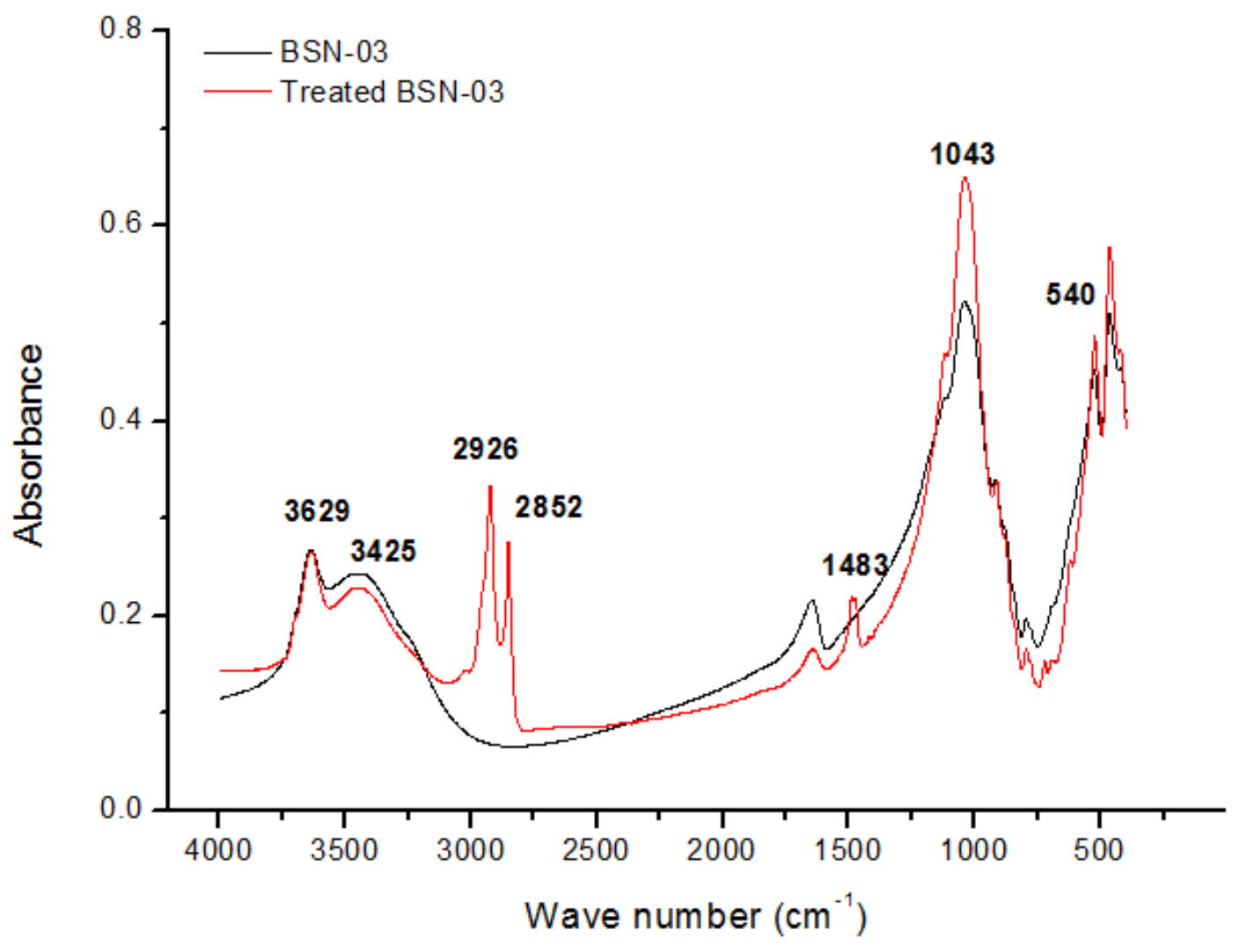

Figure 5. Infrared spectrum of untreated and treated BSN-03 clay.

The infrared spectrum of the untreated BSN-03 clay and BSN-03 treated with CTAC are shown in Figure 5.

Analyzing the bands shown in the infrared spectrum of the untreated BSN-03 clay, one can observe bands ranging from 3650 to $3400 \mathrm{~cm}^{-1}$, illustrating the presence of the hydroxyl structural group within the montmorillonites. The lower intensity of these bands on the organoclay is an evidence of changes on its surface, from hydrophilic to organophilic. The bands shown in the treated clay spectrum between 2950 and $2850 \mathrm{~cm}^{-1}$ indicate the presence of $\mathrm{CH}_{2}$ groups. The band $2926 \mathrm{~cm}^{-1}$ is due to asymmetrical stretching and the one at $2852 \mathrm{~cm}^{-1}$ is due to the symmetrical stretching. The asymmetric angular deformation of the $\mathrm{CH}_{3}$ groups occurs at about $1483 \mathrm{~cm}^{-1}$ (Zhou et al., 2008). In both spectra the wavenumber $1043 \mathrm{~cm}^{-1}$ can be observed, a band which is characteristic of the Si-O-Si bonds. The $540 \mathrm{~cm}^{-1}$ band corresponds to the aluminosilicate octahedral layers (Kozak \& Donka, 2004; Xi et al., 2007). The intercalation of CTAC in the interlayer of the clay can be confirmed by the appearance of bands related to the stretching of the $\mathrm{CH}_{2}$ groups and the bending of the $\mathrm{CH}_{3}$ groups in the spectrum of the treated BSN-03 clay.

The results of the thermal analysis are shown in Figures 6 and 7 for untreated and treated clay, respectively.

For the untreated clay, the curve shows an endothermic peak corresponding to the loss of free water (about $17 \%$ in mass), within the range between room temperature and 373K. From 473K to $873 \mathrm{~K}$, dehydroxylation endothermic peaks appear, and a further $3 \%$ of mass loss was attributed to the elimination of water adsorbed by metal cations such as $\mathrm{Na}^{+}$and $\mathrm{Ca}^{2+}$. The total mass loss for the untreated BSN-03 clay was $20 \%$, a result which is similar to the ones obtained by Sarier et al. (2010) and by Mota et al. (2011) for sodic montmorillonites, which were $18 \%$ and $17 \%$, respectively.

For the treated clay, a peak was also observed at room temperature and $373 \mathrm{~K}$, corresponding to $5 \%$ in water loss. This contraction, when compared to the untreated clay one, is explained by the 


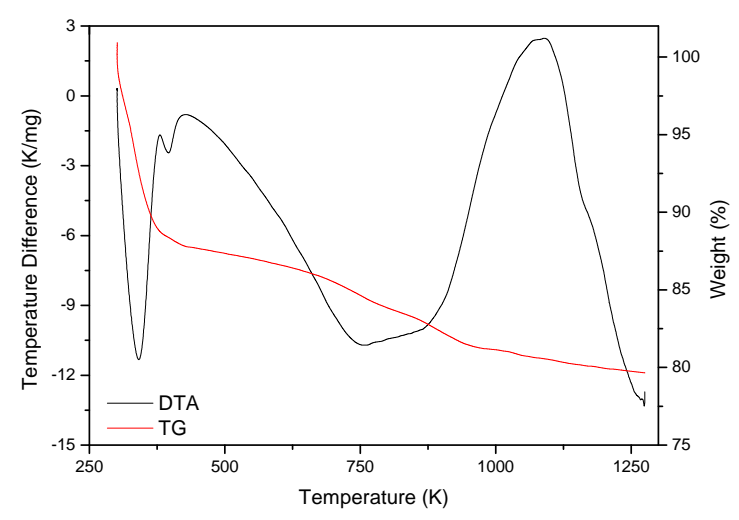

Figure 6. Thermal analysis of the untreated BSN-03 clay.

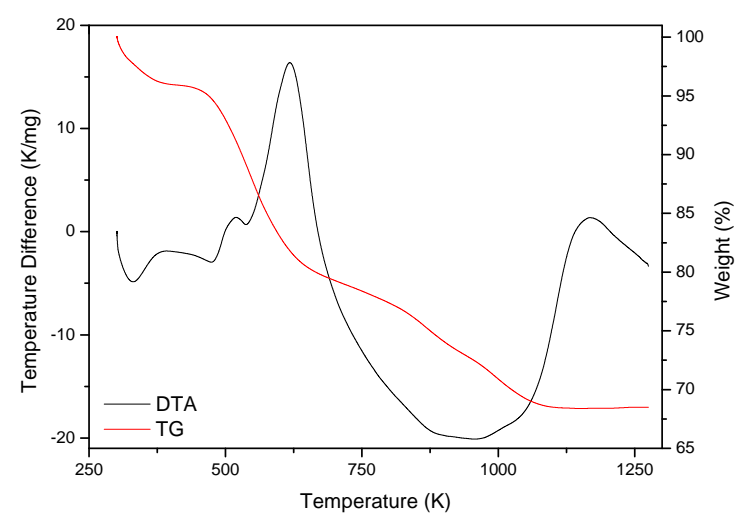

Figure 7. Thermal analysis of the treated BSN-03 clay.

conversion towards the organophilic structure. The peaks, which appear between $473 \mathrm{~K}$ and $673 \mathrm{~K}$, have a connection to the loss of organic material. The thermal degradation of the alkyl tails $\left(-\mathrm{CH}_{2}-\right)$, which is usually indicated by more than one peak, raises the possibility that the chains of the quaternary ammonium salt are positioned at more than one preferred position, if compared to the clay surface (Pereira et al., 2007), which corresponds to a mass loss of $25 \%$. The loss in mass after $673 \mathrm{~K}$, about 4 $\%$, was attributed to the removal of residual organic substances. Therefore, the total mass loss of the treated clay was around $34 \%$. For comparison, Sarier et al. (2010) reported that the results for a sodic montmorillonite treated with the sodium salt of octadecanoic acid had a total mass loss of $31 \%$. Mota et al. (2011) studied green clay treated with Dodigen, and the mass loss found was $30 \%$.

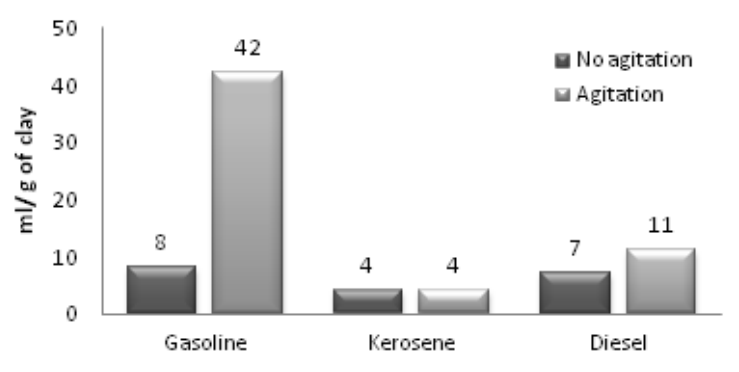

Figure 8. Results of the Foster Swelling Tests performed in different organic solvents, with and without agitation, for treated BSN-03 clay.

Some researchers argue that the various performance criteria applied to sorbents are commonly competitive. For example, a sorbent with a high value of sorption capacity is not necessarily environmentally friendly or costeffective. In general, the choice among sorbents is a compromise between performance, cost, and environmental factors.

The affinity of CTAC with organic compounds (gasoline, kerosene and diesel) was verified with the Foster Swelling Tests. The results are shown in Figure 8.

In these assays, all samples were put in contact with different organic solvents (gasoline, kerosene, and diesel). The treated sample presented a high expansion degree when tested in gasoline $(8 \mathrm{~mL} / \mathrm{g}$ of clay). Enhanced interaction ( $42 \mathrm{~mL} / \mathrm{g}$ of clay) was observed after agitation of the sample. Conversely, when mixed with kerosene the treated sample presented a low expansion degree despite performing agitation ( $4 \mathrm{~mL} / \mathrm{g}$ of clay). When diesel was used, the sample presented an intermediate expansion degree $(7 \mathrm{~mL} / \mathrm{g}$ of clay), but after agitation the expansion degree was higher $(11 \mathrm{~mL} / \mathrm{g}$ of clay).

Similar results were found by Rodrigues et al. (2010b) when assessing the swelling capacity of Brasgel clay treated with cetyltrimethylammonium bromide (CTAB) in the presence of gasoline, diesel, and kerosene. High capacity of clay adsorption was promoted by gasoline, before and after agitation. With diesel, the swelling capacity increased from intermediate to high levels upon agitation. When interacting with kerosene, the organoclay presented a low swelling capacity even after the agitation. 


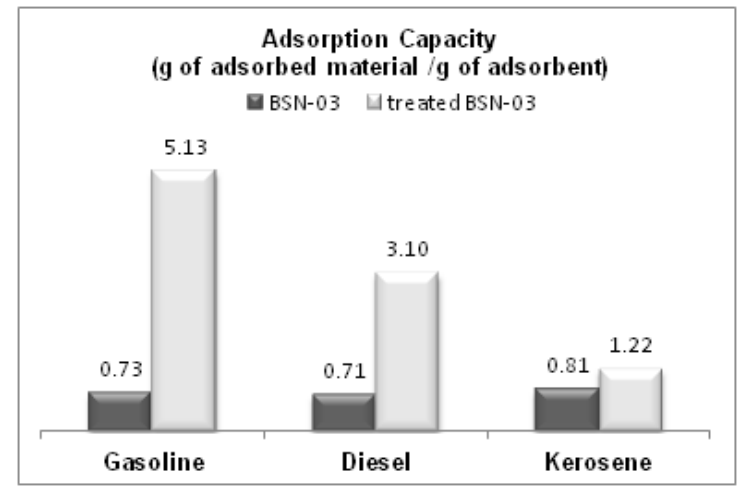

Figure 9. Adsorption capacities results of untreated and treated BSN-03.

Gonzaga et al. (2007) prepared an organoclay from Argel bentonite treated with CTAC. Using the Foster Swelling Test, it was found that in the treatment with gasoline the adsorption rate was $15 \mathrm{~mL} / \mathrm{g}$ without agitation and $17 \mathrm{~mL} / \mathrm{g}$ after agitation. With diesel, the results were $6 \mathrm{~mL} / \mathrm{g}$ without agitation and $11 \mathrm{~mL} / \mathrm{g}$ after agitation. Comparing the results obtained by Gonzaga et al. (2007) with the ones from this study, one can affirm that clay characteristics are an important differentiating factor, since the results using gasoline in various types of clay are very diverse.

The comparison between the adsorption capacities of the untreated and treated BSN-03 is shown in Figure 9. The method used to measure the hydrocarbon sorption capacity of the clays was based on the ASTM F726-99.

The CTAC-treated BSN-03 presented a significant increase in the amount of adsorbed materials. Experiments with gasoline showed that the adsorption capacity of the organoclay was $602 \%$ higher than that of the untreated clay. For diesel, the increase was around $336 \%$ in the amount of adsorbed materials by the clay. However, with kerosene, the treated BSN-03 provided the lowest increase in adsorption capacity (only 51\% higher), after the organophilization process.

The hydrocarbon sorption capacity obtained with the treated $\mathrm{BSN}-03$ was $5.13 \mathrm{~g} / \mathrm{g}$ for gasoline, $3.10 \mathrm{~g} / \mathrm{g}$ for diesel and $1.22 \mathrm{~g} / \mathrm{g}$ for kerosene. The key factor responsible for the differences in sorption capacities of treated $\mathrm{BSN}-03$ was the composition of the solvent.

Gasolines are among the lightest liquid fractions of petroleum and consist mainly of aliphatic and aromatic hydrocarbons in the carbon number range $\mathrm{C}_{4}-\mathrm{C}_{12}$. Intermediate distillates cover a broader range of hydrocarbons, typically $C_{6}-C_{25}$. They comprise kerosene and diesel $\left(C_{10}-C_{16}\right)$, and are blends of up to 500 different compounds. These intermediates tend to be denser, more viscous, less volatile, less water soluble and less mobile than gasoline. They also contain low percentages of light aromatics from the BTX group, which may not be noticeable due to degradation or transport (Weiner, 2000).

It is also known that the hydrocarbon sorption by organoclays depends on the materials and surfactants used in the modification process. Although the clay starting material plays a role, the clays and the use of different surfactants are the primary determinants which enhance hydrocarbon uptake. The influence of the clay CEC on basal spacing and surfactant packing densities has been reported in the literature (Xi et al., 2005). The result of diesel adsorption capacity with the BSN03 organophilic clay, reported in the present work, is in agreement with similar findings (Beall, 2003).

Table 4. Results of the $2^{2}$ - factorial experimental designs for treated BSN-03 clay.

\begin{tabular}{ccccccc}
\hline Assay & $\begin{array}{c}\mathrm{C}_{\mathrm{o}, \text { theo }} \\
(\mathrm{mg} / \mathrm{L})\end{array}$ & $\begin{array}{c}\mathrm{C}_{\mathrm{o} \text { real }} \\
(\mathrm{mg} / \mathrm{L})\end{array}$ & $\begin{array}{c}\text { Agitation } \\
\mathrm{rpm}\end{array}$ & $\begin{array}{c}\mathrm{C} \\
(\mathrm{mg} / \mathrm{L})\end{array}$ & $\%$ Rem & $\begin{array}{c}\mathrm{q}_{\mathrm{eq}} \\
(\mathrm{mg} / \mathrm{g})\end{array}$ \\
\hline 1 & 100 & 98 & 0 & 28.78 & 71.22 & 7.12 \\
2 & 500 & 500 & 0 & 37.41 & 92.52 & 46.26 \\
3 & 100 & 98 & 200 & 5.58 & 94.42 & 9.44 \\
4 & 500 & 500 & 200 & 5.05 & 98.99 & 49.50 \\
5 & 300 & 302 & 100 & 3.82 & 98.73 & 29.82 \\
6 & 300 & 302 & 100 & 10.26 & 96.60 & 29.17 \\
7 & 300 & 302 & 100 & 6.28 & 97.92 & 29.57 \\
\hline
\end{tabular}


Table 5. Analysis of variance for the percentage of oil removal with treated BSN-03 clay.

\begin{tabular}{ccccc}
\hline Sources & $\mathrm{df}$ & $\mathrm{SM}$ & $\mathrm{MS}$ & $\mathrm{p}$ \\
\hline Main effect & 2 & 387.285 & 193.643 & 0.006 \\
Interaction & 1 & 69.896 & 69.896 & 0.016 \\
Curvature & 1 & 122.861 & 122.861 & 0.009 \\
Residual error & 2 & 2.316 & 1.158 & - \\
Pure error & 2 & 2.316 & 1.158 & - \\
Total & 6 & 582.358 & - & - \\
$\mathrm{R}^{2}=0.9881$ & $\mathrm{R}_{\text {max }}^{2}=0.9996$ & & \\
\hline
\end{tabular}

Table 6. Analysis of variance for the oil removal capacity with treated BSN-03 clay.

\begin{tabular}{clccc}
\hline Sources & df & SM & MS & $p$ \\
\hline Main effect & 2 & 1575.49 & 787.75 & 0.000 \\
Interaction & 1 & 0.21 & 0.21 & 0.294 \\
Curvature & 1 & 3.56 & 3.56 & 0.028 \\
Residual error & 2 & 0.21 & 0.11 & - \\
Pure error & 2 & 0.21 & 0.11 & - \\
Total & 6 & 1579.48 & - & - \\
$\mathrm{R}^{2}=0.9996$ & $\mathrm{R}_{\text {max }}^{2}=0.9999$ & & \\
\hline
\end{tabular}

The efficiency of treated clay in the removal of emulsified oil in water was evaluated by finite bath tests following a $2^{2}$ factorial design (Table 2 ). The percentage of oil removal (\%Rem) and the removal capacity $\left(\mathrm{q}_{\mathrm{eq}}\right)$ are shown in Table 4 , where $C_{o \text {,theo }}$ refers to the estimated initial oil concentration in the emulsion, $C_{o, \text { real }}$ is the real concentration of oil in the emulsion and $C$ is the final oil concentration, after the assay.

To determine the percentage of removal and the removal capacity, an analysis of variance (ANOVA) was performed. The results are presented in Tables 5 and 6, where $\mathrm{df}$ are the degrees of freedom, SM refers to the sum of squares, MS refers to mean squares, and $p$ is the probability value.

The analysis of Table 5 illustrates the main effects of agitation (A) and the initial concentration (Co). The interactions were significant at the $5 \%$ level for the percentage of oil removal. The analysis suggests a quadratic model for \%Rem expressed by Equation 3. The data shown in Table 6 indicate that the oil removal capacity is also modeled by a quadratic function (Equation 4). The interaction between the factors did not significantly affect the response. The model fitting is improved significantly, leading to correlation coefficients $\left(R^{2}\right)$ as high as $98.81 \%$ for \%Rem and $99.96 \%$ for $q_{\text {eq }}$.

$\%$ Rem $=99.753+6.467 \mathrm{C}_{\mathrm{o}}+7.416 \mathrm{~A}_{\mathrm{m}}-$

$-8.466 \mathrm{C}_{\mathrm{o}}{ }^{2}-4.180 \mathrm{C}_{\mathrm{o}} \cdot \mathrm{A}_{\mathrm{m}}$

$\mathrm{q}_{\mathrm{eq}}=29.5213+19.7976 \mathrm{C}_{\mathrm{o}}+$

$+1.3887 \mathrm{~A}_{\mathrm{m}}-1.4417 \mathrm{C}_{\mathrm{o}}{ }^{2}$

Equations 3 and 4 are plotted as response surfaces for the percentage of oil removal (Figure 10a) and oil capacity (Figure 10b) with the treated BSN-03 clay. By examining these surfaces, the influence of the factors on the responses can be better understood. For \%Rem one can see clearly that the influence of the initial concentration on the response is more pronounced than the agitation of the system $\left(A_{m}\right)$. This is also the case for $\mathrm{q}_{\mathrm{eq}}$ in which data (Figure 10b) show that changes in the initial oil concentration alter the overall removal capacity more than variations in 


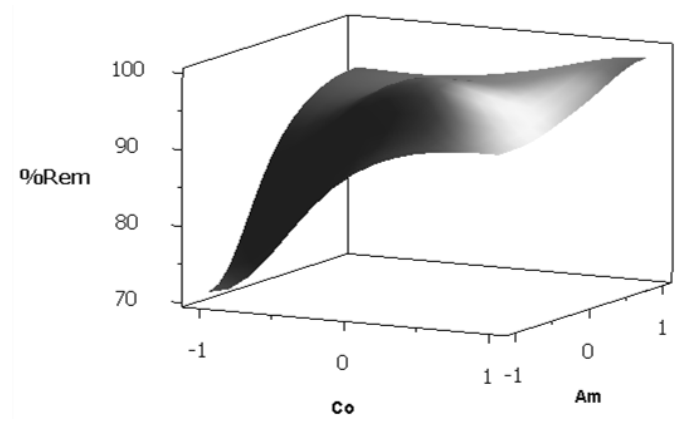

(a)

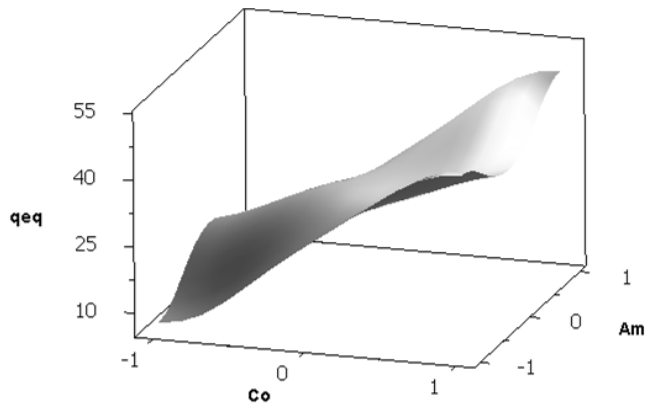

(b)

Figure 10. Response Surfaces for the (a) percentage of oil removed from emulsions and (b) oil removal capacity with the treated BSN-03 clay.

the agitation of the bath system, although the response is not affected greatly by interactions between these factors.

\section{CONCLUSIONS}

In this study, synthesized was tested for processing oil emulsions and water separation. The organoclay used on the experiments was obtained by a synthesis of natural sodium clay (BSN-03) from Argentina with surfactant cetyltrimethylammonium chloride (CTAC) through ion exchange. The main findings are summarized as follows:

- The results of Cation Exchange Capacity suggest that the interlayer cations of the clay are exchanged with the quaternary cations of the surfactant. The diffractogram and the infrared spectra confirmed the intercalation of the cations in the clay lamella, with an increase in the basal distance and the appearance of bands of organic compounds.

- The adsorption capacity assays showed that treated clay adsorbed organic solvents (gasoline, kerosene, and diesel) more efficiently than untreated clay.

- The Swelling Foster Test exhibited a high degree of swelling in gasoline after agitation with the treated BSN-03 clay.

- In light of the results, based on the oil removal oil test, the organoclay showed a good efficiency in the process, removing up to $98.99 \%$ of the pollutant. One particular set of data obtained with agitation rates of 200rpm and an initial concentration of oil of 100ppm showed a removal capacity of $49.50 \mathrm{mg}$ of oil per gram of clay. Analyzing these results, one can conclude that the BSN-03 clay treated with CTAC is an efficient and low-cost alternative in the treatment of produced water.

\section{ACKNOWLEDGEMENTS}

The authors gratefully acknowledge CAPES, Clariant, Petrobras and CETENE.

\section{REFERENCES}

Alther, G. Cleaning wastewater: Removing oil from water with organoclays. Filtration \& Separation, v.45, p.22-24, 2008.

http://dx.doi.org/10.1016/S0015-1882(08)70057-0

ASTM. Standard Methods of Testing Sorbent Performance of Adsorbents - Designation: ASTM F726 -99.

ASTM. Standard Methods of Testing Sorbent Performance of Adsorbents - Designation: ASTM F716-82 (Reapproved 1993).

ASTM. Standard Methods of Testing Sorbent Performance of Adsorbents - Designation: D589095. 
ASTM. Standard Methods of Testing Sorbent Performance of Adsorbents - Designation: D750310.

Bande, R. M.; Prasad, B.; Mishra, I. M.; Wasewar, K. L. Oil field effluent water treatment for safe disposal by electroflotation. Chemical Engineering Journal, v.137, p. 503-509, 2008. http://dx.doi.org/10.1016/i.cej.2007.05.003

Beall, G. W. The use of organo-clays in water treatment. Applied Clay Science. v.24, p.11-20, 2003. http://dx.doi.org/10.1016/j.clay.2003.07.006

Bergaya, F.; Lagaly, G. Surface modification of clay minerals. Applied Clay Science, v.19, p.1-3, 2001.

http://dx.doi.org/10.1016/S0169-1317(01)00063-1

Bergaya, F.; Theng, B. K. G.; Lagaly, G. Handbook of Clay Science. Elsevier, 1246p, 2006.

Brindley, G. W.; Brown, G. Crystal structures of clay minerals and their $X$-ray identification. Mineralogical Society, 170p, 1980.

Campos, J. C.; Borges, R. M. H.; Filha, A. M.; Oliveira, N. R. Oilfield wastewater treatment by combined microfiltration and biological processes. Water Research, v.36, p. 95-104, 2002. http://dx.doi.org/10.1016/50043-1354(01)00203-2

Gonzaga, A. C.; Sousa, B. V.; Santana, L. N. L.; Neves, G. A.; Rodrigues, M. G. F. Study of different methods in the preparation of organoclays from the bentonite with application in the petroleum industry. Brazilian Journal of Petroleum and Gas, v.1, p. 16-25, 2007.

Greenberg, A. E.; Trussell, R. R.; Clesceri, L. S. Standard methods for the examination of water and wastewater. American Public Health Association Publications, p.498-499, 1985.

Grim, R.E. Clay Minerology. Science, 890p, 1962. http://dx.doi.org/10.1126/science.135.3507.890

Henderson, S. B.; Grigson, S. J. W.; Johnson, P. E.; Roddie, B. D. Potential impact of production chemicals on the toxicity of produced water discharges from North Sea oil platforms. Marine Pollution Bulletin, v.38, p. 1141-1151, 1999. http://dx.doi.org/10.1016/S0025-326X(99)00144-7
Kozak, M.; Donka, L. Adsorption of the quaternary ammonium salts on montmorillonite. Journal of Physical and Chemistry Solids, v.65, p.441-445, 2004.

http://dx.doi.org/10.1016/i.jpcs.2003.09.015

Mota, M. F.; Silva, J. A.; Queiroz, M. B.; Laborde, H. M.; Rodrigues, M. G. F. Organophilic clay for oil/water separation process by finite bath tests. Brazilian Journal of Petroleum and Gas, v.5, p.97107, 2011. http://dx.doi.org/10.5419/bjpg2011-0011

Okiel, K; El-Sayed, M; El-Kady, M. Y; Treatment of oil-water emulsions by adsorption onto activated carbon, bentonite and deposited carbon. Egyptian Journal of Petroleum, v.20, p.9-15, 2011. http://dx.doi.org/10.1016/i.ejpe.2011.06.002

Pereira, K. R. O.; Rodrigues, M. G. F.; Valenzuela-Diaz, F. R. Síntese e caracterização de argilas organofílicas: comparação no uso de dois métodos, Revista Eletrônica de Materiais e Processos, v. 2, p. 1-8, 2007. (In Portuguese)

Rodrigues, M. G. F.; Physical and catalytic characterization of smectites from Boa Vista, Paraíba, Brazil. Cerâmica, v.49, p.146-150, 2003. http://dx.doi.org/10.1590/S0366-69132003000300007

Rodrigues, S. C. G.; Rodrigues, M. G. F.; Pereira, K. R. O.; Valenzuela-Diaz, F. R. Performance of organophilic clay as adsorbent in the oil/water separation process. Brazilian Journal of Petroleum and Gas, v.4, p. 49-58, 2010a.

Rodrigues, S. C. G.; Queiroz, M. B.; Pereira, K. R. O.; Rodrigues, M. G. F.; Valenzuela-Diaz, F. R. Comparative Study of Organophilic Clays to be Used in the Gas and Petrol Industry. Materials Science Forum, v.660-661, p. 1037-1042, 2010b. http://dx.doi.org/10.4028/www.scientific.net/MSF.660$\underline{661.1037}$

Sarier, N; Onder, E; Ersoy, S. The modification of Na-montmorillonite by salts of fatty acids: An easy intercalation process. Colloids and Surfaces A: Physicochemical and Engineering Aspects, v.371, p.40-49, 2010.

http://dx.doi.org/10.1016/i.colsurfa.2010.08.061

Scholz, W.; Fuchs, W. Treatment of oil contaminated wastewater in a membrane bioreactor. Water Research, v.34, p.3621-3629, 2000.

http://dx.doi.org/10.1016/50043-1354(00)00106-8 
Sousa Santos, P. Ciência e Tecnologia de Argilas. São Paulo: Ed. Edgard Blücher, 408p,1989. (In Portuguese)

Srivastava, V. C.; Swamy, M. M.; Mall, I. D.; Prasad, B.; Mishra, I. M. Adsorptive removal of phenol by bagasse fly ash and activated carbon: Equilibrium, kinetics and thermodynamics. Colloids and Surfaces A: Physicochemical and Engineering Aspects, v.272, p.89-104, 2006.

http://dx.doi.org/10.1016/i.colsurfa.2005.07.016

Weiner, E. R. Applications of Environmental Chemistry. New York: Lewis Publishers, 298p, 2000. http://dx.doi.org/10.1201/9781420032963

Xi, Y.; Frost, R. L.; He, H.; Kloprogee, T.; Bostroom, T. Modification of Wyoming Montmorillonite Surfaces Using a Cationic Surfactant. Langmuir, v.21, p.8675-8680, 2005.http://dx.doi.org/10.1021/la051454i
Xi, Y.; Frost, R. L; He, H. Modification of the surfaces of Wyoming montmorillonite by the cationic surfactants alkyl trimethyl, dialkyl dimethyl, and trialkyl methyl ammonium bromides. Journal of Colloid and Interface Science, v.305, p.150-158, 2007.

http://dx.doi.org/10.1016/j.jcis.2006.09.033

Yuri, P.; Ayoko, G. A.; Frost, R. L. Application of organoclays for the adsorption of recalcitrant organic molecules from aqueous media. Journal of Colloid and Interface Science, v.354, p.292-305, 2011. http://dx.doi.org/10.1016/i.jcis.2010.09.068

Zhou, Q.; Xi, Y.; He, H.; Frost, R. Application of near infrared spectroscopy for the determination of adsorbed p-nitrophenol on HDTMA organoclaysimplications for the removal of organic pollutants from water. Spectrochimica A: Molecular and Biomolecular Spectroscopy, v.69, p.835-841, 2008. http://dx.doi.org/10.1016/j.saa.2007.05.037 